\title{
The Female Frame: Biopolitics and Wellbeing in Australian and Global Perspective
}

Iva Glisic, Samantha Owen, Parisa Shams, Kelly Bailey, Michelle Bootcov, Jessica Murray and Lee Sulkowska Australian Women's History Network Convenors

This special section of Lilith: A Feminist History Journal emerged from the Australian Women's History Network (AWHN) Symposium, held at the University of Western Australia on 2 October 2019. The theme of the symposium was 'The Female Frame: Biopolitics and Wellbeing in Australian and Global Perspective'. We used the phrase 'female frame' as a catalyst for discussion on the way bodies are socially constructed and gendered, while the different theoretical inflections of 'biopolitics' pressured disciplinary bounds as part of our mission to expand AWHN's scope into cognate disciplines, including policy and advocacy. In another motion to widen the network's focus, we sought to invite thinking on the connections between Australian history and broader global or transnational contexts. The symposium theme's emphasis on wellbeing and health, an emphasis that has motivated our term as AWHN convenors, has assumed new and critical significance with the global coronavirus outbreak in late 2019, and its ongoing effects.

The symposium opened insightful conversations on the female frame as function, source and signifier of change and growth, and presenters approached the theme from diverse perspectives. Papers ranged from considering the representation of women in public spaces, institutions and masculinised environments to gendered expectations of women and reflections on female identity, migration and mobility. Furthermore, the symposium included keynote addresses from Professor Tanya Fitzgerald, on the intimate friendship between Virginia Gildersleeve and Caroline Spurgeon through the International Federation of University Women, and from Emerita Professor Ann Curthoys, on African-American feminist Eslanda Robeson's visit to Perth in 1960. 
The two articles comprising the special section capture these diverse perspectives and thematic breadth: Emma Robertson and Lee-Ann Monk, in an article arising from an AWHN symposium presentation with Diane Kirkby, trace the shifting attitudes to women's clothing in maledominated transport industries in Britain and Australia in the twentieth century. "In Donkey Jacket and Doc Martin Boots": Women Workers, Uniforms and the Patterning of Exclusion in the Male-Dominated Transport Industry' examines the symbolic dimension of this clothing, which was bound up in assumptions about the 'female frame' and women's bodies, and the ways this led to a 'patterning of exclusion'. Saskia Roberts, in 'Maternity Misplaced: The Infanticidal Mother Archetype in Fin-de-siècle Australia and France', focuses on the archetype of the infanticidal mother in late nineteenth-century Australia and France through newspaper reports and fictional serials to argue that it affirmed contemporary gender norms by reifying ideals of motherhood. Despite the distinct interests and approaches of the two articles, bridging them is their exploration of the 'female frame' as registering contesting political attitudes, and an investment in revealing transnational connections (and differences) that studies with a more national (or Anglophone) focus have overlooked. This special section thus speaks more broadly to a growing emphasis on the possibilities and tensions of examining feminist history in global perspective. 
This text is taken from Lilith: A Feminist History Journal: Number 27, published 2021 by ANU Press, The Australian National University,

Canberra, Australia.

doi.org/10.22459/LFHJ.27.08 